\section{Early determinants of smoking in adolescence: a prospective birth cohort study}

\author{
Determinantes precoces do fumo na adolescência: \\ uma coorte de nascimentos prospectiva
}

\author{
1 Programa de Pós-graduação \\ em Epidemiologia, \\ Universidade Federal \\ de Pelotas, Pelotas, Brasil. \\ Correspondence \\ A. M. B. Menezes \\ Programa de Pós-graduação \\ em Epidemiologia, \\ Universidade Federal de \\ Pelotas. \\ Av. Domingos de Almeida \\ 1146, apto. 25, Pelotas, RS \\ 96085-470, Brasil. \\ anamene@terra.com.br
}

\section{Abstract}

In a prospective birth cohort study in Brazil, the prevalence and early risk factors for smoking in adolescence were investigated. All 1982 hospital-born children in Pelotas, Rio Grande do Sul, Brazil, were enrolled in a birth cohort study ( $N=5$,914; boys: 3,037; girls: 2,877). All male participants were searched in 2000 when enrolling in the national army, and $78.8 \%$ were traced. In 2001, a systematic sample of 473 girls was interviewed, representing a follow-up rate of 69.1\%. Among males, 48.6\% (95\%CI: 46.650.7) had ever tried smoking and $15.8 \%$ (95\%CI: 14.3-17.3) were daily smokers. Among females, 53.1\% (95\%CI: 48.6-57.6) had ever tried smoking and 15.4\% (95\%CI: 12.1-18.7) were daily smokers. Boys born to single mothers and those with fathers with low schooling were more likely to smoke in adolescence. Girls from low-income families, with mothers who smoked during pregnancy, and fathers with alcohol-related problems were more likely to smoke. Although the smoking prevalence was similar in boys and girls, risk factors for smoking were different between the sexes. Social environment appears to be the strongest predictor of tobacco use in adolescence.

Tobacco;Adolescent Behavior; Prospective Studies
Ana M. B. Menezes 1

Pedro C. Hallal 1

Bernardo L. Horta 1

\section{Introduction}

Although the prevalence of smoking in adult males is decreasing slightly in Latin America, the same is not true for females 1 . Two groups of the general population have been the main targets for the addiction of smoking: females and teenagers. In countries such as China, where women have only recently been allowed to smoke, an epidemic of smoking is predicted in the near future 1 . Among adolescents, no evidence of decline in the prevalence of smoking is available 1. In Brazil, 2.7 million adolescents were smokers in 1989, which represented a prevalence rate of $9 \%{ }^{2}$. In 2001, $15.7 \%$ of all adolescents aged 12-17 years had ever tried tobacco ${ }^{3}$.

Identification of risk factors for smoking is a public health priority. A recent literature review 4 identified the following significant risk factors for adolescent tobacco use: smoking among friends and siblings, poor academic performance, being older, male gender, labor, and parents who were separated. However, most papers on risk factors for smoking in adolescence are cross-sectional, analyzing exposures and outcomes simultaneously, and are thus prone to reverse causality bias.

Currently, there is growing interest in the idea of programming health outcomes 5 . So far, most of these studies have focused on biological outcomes such as coronary heart disease, diabetes, hypertension, and obesity 6,7,8,9,10. However, be- 
haviors might also be programmed during early life ${ }^{11}$. In a prospective birth cohort study in Brazil, we investigated the prevalence and early risk factors for smoking in adolescence.

\section{Methods}

The study was conducted in Pelotas, Rio Grande do Sul, a relatively well-developed city in Southern Brazil (current population 320,000), located near the border with Uruguay and Argentina. The per capita gross domestic product in Pelotas is US\$ 2,700 12. The population is mostly white, of Portuguese and Spanish ancestry. Among adults ( $\geq 20$ years), prevalence of current smoking in males and females is $32.8 \%$ and $24.1 \%$, respectively 13 .

In 1982, the three maternity hospitals in the city were visited daily, and all 5,914 live births whose families lived in the urban area of the city were included in a birth cohort study. Mothers were interviewed soon after birth using a standardized pre-tested questionnaire on demographic, socioeconomic, behavioral, and gestational variables. Newborns were weighed with pediatric scales. The cohort children were followed up at several points in time. In 1984 (mean age 20 months), a citywide census was conducted to locate children born in 1982, and $87 \%$ of the cohort was located. A similar census was repeated in 1986 (mean age 42 months), when $84 \%$ of the children were located. In these two follow-up visits, mothers were interviewed and information on behavior, such as smoking and alcohol-related problems, was collected. Paternal data were obtained from the mothers.

In 2000, all males from the birth cohort were legally required to undergo a medical examination at the local Army Base. They were then invited to answer a research questionnaire that included several health-related data. Adolescents who did not attend the Army examination were traced at their last known address and invited to attend an examination at a clinic. Those who still failed to attend were visited at home.

Because the Army Enlistment Study was restricted to males, it was desirable to obtain similar information for the female adolescents in the cohort. In 2001, a systematic sample of 70 out of the 259 census tracts in the city was selected. In each tract, all households were visited and female adolescents born in 1982 were interviewed.

In the 2000 and 2001 visits, adolescents were asked about tobacco smoking. Daily smoking was defined as at least one cigarette per day on each day of the previous week. Weekly smoking was defined as at least one day of smoking in the previous week.
The following early predictors of tobacco smoking were considered: self-reported maternal skin color (white, non-white), maternal marital status at delivery (married, unmarried), family income at delivery (in minimum wages), maternal schooling (years of formal education), paternal schooling (years of formal education), maternal age at delivery $(<20,20-29, \geq 30$ years), maternal smoking during pregnancy (no, 1-14, $\geq 15$ cigarettes per day), paternal alcohol-related problems (a dichotomous variable based on maternal self-report), and maternal and paternal smoking during child's infancy (no, 1-14, $\geq 15$ cigarettes per day).

Following descriptive analyses, the prevalence of daily and weekly smoking was calculated for each group of the independent variables. Chisquare tests for heterogeneity and trend were used to calculate significance. Logistic regression models were used for multivariate analyses, using a hierarchical approach. Order of entry into the model was based on a conceptual framework defined a priori 14 . The first level incorporated the variables: maternal skin color, maternal marital status, family income, maternal and paternal schooling, and maternal age. The second level included smoking during pregnancy, paternal alcohol-related problems, and maternal and paternal smoking during child's infancy. The effect of each exposure on the outcome was adjusted for covariates in the same level or above in the hierarchical model ${ }^{14}$. All analyses were carried out separately for males and females, and interactions between gender and other covariates were tested. Weighted analyses were not necessary because no pooled estimates were presented. All tests were two-tailed and the significance level was $5 \%$.

The Research Ethics Committee at the Medical School of the Federal University in Pelotas approved the study protocol, and informed consent was obtained in all phases of the birth cohort study. Further details on the cohort study methodology are available elsewhere 15 .

\section{Results}

The original 1982 cohort included 5,914 individuals (boys: 3,037; girls: 2,877). The overall followup rate in the Army study was $78.9 \%$; this analysis included 2,245 males. In the female sub-study, which included $27 \%$ of all females belonging to the cohort, the follow-up rate was $69.1 \%$, and analyses were carried out for 473 adolescent girls. Table 1 presents follow-up rates according to baseline characteristics. Non-response was higher among adolescents from low socioeconomic 
Percentage of individuals located in late adolescence according to key baseline characteristics.

\begin{tabular}{|c|c|c|c|c|}
\hline \multirow[t]{2}{*}{ Baseline variables (1982) } & \multicolumn{2}{|c|}{ Original cohort number } & \multicolumn{2}{|c|}{ Percent located } \\
\hline & Male & Female & Male & Female * \\
\hline \multicolumn{5}{|c|}{ Family income (minimum wage) } \\
\hline$\leq 1$ & 666 & 622 & 73 & 61 \\
\hline $1.1-3.0$ & 1,463 & 1,325 & 80 & 69 \\
\hline $3.1-6.0$ & 544 & 547 & 84 & 78 \\
\hline $6.1-10$ & 184 & 198 & 79 & 68 \\
\hline$>10$ & 167 & 168 & 77 & 81 \\
\hline \multicolumn{5}{|l|}{ Maternal schooling (years) } \\
\hline $0-4$ & 1,008 & 952 & 76 & 62 \\
\hline $5-8$ & 1,288 & 1,166 & 82 & 73 \\
\hline $9-11$ & 330 & 324 & 76 & 63 \\
\hline$\geq 12$ & 406 & 432 & 80 & 81 \\
\hline \multicolumn{5}{|l|}{ Birth weight (grams) } \\
\hline$<2,500$ & 244 & 289 & 79 & 69 \\
\hline$\geq 2,500$ & 2,791 & 2,584 & 77 & 72 \\
\hline \multicolumn{5}{|l|}{ Maternal skin color } \\
\hline White & 2,479 & 2,371 & 79 & 70 \\
\hline Non-white & 556 & 504 & 78 & 67 \\
\hline \multicolumn{5}{|l|}{ Maternal marital status } \\
\hline Married & 2,789 & 2,635 & 79 & 70 \\
\hline Single & 246 & 238 & 73 & 62 \\
\hline \multicolumn{5}{|c|}{ Maternal smoking during pregnancy } \\
\hline No & 1,946 & 1,864 & 80 & 70 \\
\hline Yes & 1,091 & 1,012 & 75 & 66 \\
\hline
\end{tabular}

* Values obtained in a systematically-selected sub-sample of $27 \%$ searched at 19 years, and then extrapolated proportionately to the entire cohort.

status families. Birth weight, maternal skin color, and maternal smoking during pregnancy were not associated with follow-up rates. Adolescents born to unmarried women were less likely to be followed-up.

Among males, 48.6\% (95\%CI: 46.6-50.7) had ever tried smoking, $20.2 \%$ (95\%C: 18.6-21.9) had smoked at least one day in the previous week, and $15.8 \%$ (95\%CI: 14.3-17.3) were daily smokers. Among male current smokers, the mean number of cigarettes per day was $10.0(\mathrm{SD}=6.9)$. Most male smokers $(54.3 \%)$ had started smoking between 13 and 15 years of age, while $11.5 \%$ had started smoking before reaching 13. Among females, $53.1 \%$ (95\%CI: 48.6-57.6) had ever tried smoking, 19.9\% (95\%CI: 16.3-23.5) had smoked at least one day in the previous week, and $15.4 \%$ (95\%CI: 12.1-18.7) were daily smokers. The mean number of cigarettes smoked per day among female smokers was 8.4 ( $\mathrm{SD}=7.8$ ). The proportion of girls who had started smoking before reaching 13 was $18 \% ; 47.4 \%$ had started between 13 and 15 years of age.
Table 2 shows the prevalence and risk factors for daily and weekly smoking for boys and girls separately. Among boys, daily smoking was more common among those born to single mothers and presented an inverse association with maternal and paternal schooling. The determinants of weekly smoking were all consistent with those observed for daily smoking.

Among girls, daily smoking was positively associated with exposure to maternal smoking during pregnancy and childhood, as well as paternal alcohol-related problems. The association was negative for family income and maternal schooling. Analyses of weekly smoking produced results comparable to those obtained with the outcome daily smoking (Table 2).

Table 3 presents the multivariate analyses for the two outcomes (daily and weekly smoking) among boys and girls separately. The effect of maternal marital status on the prevalence of smoking in boys remained unaltered after adjustment. The variable maternal schooling lost significance after adjustment, and paternal edu- 
Prevalence of daily and weekly smoking among adolescents according to independent variables.

\begin{tabular}{|c|c|c|c|c|}
\hline \multirow[t]{2}{*}{ Variable } & \multicolumn{2}{|c|}{ Males $(\mathrm{N}=2,245)$} & \multicolumn{2}{|c|}{ Females $(N=473)$} \\
\hline & $\begin{array}{c}\% \text { daily } \\
\text { smoking (N) }\end{array}$ & $\begin{array}{l}\text { \% weekly } \\
\text { smoking (N) }\end{array}$ & $\begin{array}{c}\% \text { daily } \\
\text { smoking (N) }\end{array}$ & $\begin{array}{c}\% \text { weekly } \\
\text { smoking (N) }\end{array}$ \\
\hline Maternal skin color & $p=0.45$ & $p=0.29$ & $p=0.17$ & $p=0.09$ \\
\hline White & $15.6(288)$ & $19.8(367)$ & $14.4(56)$ & $18.5(72)$ \\
\hline Non-white & $17.1(67)$ & $22.2(87)$ & $20.8(16)$ & $27.3(21)$ \\
\hline Maternal marital status & $p=0.02$ & $p=0.02$ & $p=0.97$ & $p=0.86$ \\
\hline Married & $15.3(319)$ & $19.7(410)$ & $15.4(67)$ & $20.0(87)$ \\
\hline Single & $22.5(36)$ & $27.5(44)$ & $15.6(5)$ & $18.8(6)$ \\
\hline Family income (minimum wage) & $p=0.07$ * & $p=0.09$ * & $p=0.01 *$ & $p=0.01 *$ \\
\hline$\leq 1$ & $16.7(70)$ & $19.8(83)$ & $21.8(17)$ & $28.2(22)$ \\
\hline $1.1-3.0$ & $16.8(185)$ & $21.9(242)$ & $17.8(39)$ & $22.4(49)$ \\
\hline $3.1-6.0$ & $14.6(65)$ & $18.7(83)$ & $9.5(10)$ & $12.4(13)$ \\
\hline $6.1-10.0$ & $16.1(23)$ & $20.3(29)$ & $13.8(4)$ & $17.2(5)$ \\
\hline$>10.0$ & $9.5(12)$ & $12.7(16)$ & $5.7(2)$ & $11.4(4)$ \\
\hline Maternal schooling (years) & $p=0.01 *$ & $p<0.001^{*}$ & $p=0.02$ * & $p=0.04$ * \\
\hline $0-4$ & $18.2(127)$ & $22.7(158)$ & $21.5(29)$ & $25.9(35)$ \\
\hline $5-8$ & $15.1(149)$ & $20.1(198)$ & $15.2(29)$ & $19.9(38)$ \\
\hline $9-11$ & $19.0(46)$ & $21.5(52)$ & $6.7(4)$ & $10.0(6)$ \\
\hline$\geq 12$ & $10.1(32)$ & $13.9(44)$ & $12.3(10)$ & $17.3(14)$ \\
\hline Paternal schooling (years) & $p<0.001$ * & $\mathrm{p}<0.001$ * & $p=0.42$ * & $p=0.45 *$ \\
\hline $0-4$ & $20.9(106)$ & $26.2(133)$ & $17.4(16)$ & $22.8(21)$ \\
\hline $5-8$ & $14.8(132)$ & $19.4(173)$ & $15.9(32)$ & $18.9(38)$ \\
\hline$\geq 9$ & $13.6(74)$ & $16.7(91)$ & $13.5(16)$ & $18.5(22)$ \\
\hline Maternal age (years) & $p=0.56$ & $p=0.80$ & $p=0.39$ & $p=0.47$ \\
\hline$<20$ & $15.0(48)$ & $19.4(62)$ & $8.3(5)$ & $13.3(8)$ \\
\hline $20-29$ & $16.7(220)$ & $20.9(275)$ & $17.1(43)$ & $21.4(54)$ \\
\hline$\geq 30$ & $14.3(87)$ & $19.3(117)$ & $15.5(24)$ & $20.0(31)$ \\
\hline \multicolumn{5}{|l|}{ Maternal smoking during } \\
\hline pregnancy (cigarettes/day) & $p=0.12$ & $p=0.13$ & $p<0.001$ & $p<0.001$ \\
\hline No & $14.9(220)$ & $19.0(281)$ & $11.6(36)$ & $17.1(53)$ \\
\hline $1-14$ & $17.5(100)$ & $23.1(132)$ & $19.5(23)$ & $21.2(25)$ \\
\hline$\geq 15$ & $17.8(35)$ & $20.8(41)$ & $33.3(13)$ & $38.5(15)$ \\
\hline Paternal alcohol-related problems & $p=0.33$ & $p=0.27$ & $p=0.001$ & $p=0.01$ \\
\hline No & $15.4(256)$ & $19.8(329)$ & $13.1(48)$ & $17.7(65)$ \\
\hline Yes & $19.2(18)$ & $24.5(23)$ & $45.0(9)$ & $45.0(9)$ \\
\hline \multicolumn{5}{|l|}{ Maternal smoking in child's } \\
\hline infancy (cigarettes/day) & $p=0.33$ & $p=0.31$ & $p=0.02$ & $p=0.06$ \\
\hline No & $15.4(188)$ & $19.6(240)$ & $12.5(33)$ & $17.8(47)$ \\
\hline $1-14$ & $18.7(79)$ & $23.7(100)$ & $18.4(18)$ & $21.4(21)$ \\
\hline$\geq 15$ & $16.6(61)$ & $20.9(77)$ & $23.6(17)$ & $27.8(20)$ \\
\hline \multicolumn{5}{|l|}{ Paternal smoking in child's } \\
\hline infancy (cigarettes/day) & $p=0.20$ & $p=0.09$ & $p=0.20$ & $p=0.08$ \\
\hline No & $14.0(96)$ & $17.6(121)$ & $13.0(22)$ & $16.0(27)$ \\
\hline $1-14$ & $17.0(54)$ & $22.3(71)$ & $10.3(6)$ & $15.5(9)$ \\
\hline$\geq 15$ & $16.5(124)$ & $21.3(160)$ & $18.1(29)$ & $23.8(38)$ \\
\hline
\end{tabular}

* $p$ values for linear trend. 
Multivariate analyses of early determinants of daily and weekly smoking in boys and girls.

\begin{tabular}{|c|c|c|c|c|}
\hline \multirow[t]{2}{*}{ Variable } & \multicolumn{2}{|c|}{ Males $(\mathrm{N}=2,245)$} & \multicolumn{2}{|c|}{ Females $(N=473)$} \\
\hline & $\begin{array}{l}\text { Daily smoking } \\
\text { OR }(95 \% \mathrm{Cl})\end{array}$ & $\begin{array}{l}\text { Weekly smoking } \\
\text { OR }(95 \% \mathrm{Cl})\end{array}$ & $\begin{array}{l}\text { Daily smoking } \\
\text { OR }(95 \% \mathrm{Cl})\end{array}$ & $\begin{array}{l}\text { Weekly smoking } \\
\text { OR }(95 \% \mathrm{Cl})\end{array}$ \\
\hline Maternal skin color & $p=0.26$ & $p=0.73$ & $p=0.50$ & $p=0.67$ \\
\hline White & 1.00 & 1.00 & 1.00 & 1.00 \\
\hline Non-white & $0.82(0.58-1.15)$ & $0.95(0.70-1.29)$ & $1.28(0.63-2.60)$ & $1.16(0.59-2.25)$ \\
\hline Maternal marital status & $p=0.01$ & $p=0.007$ & $p=0.60$ & $p=0.42$ \\
\hline Married & 1.00 & 1.00 & 1.00 & 1.00 \\
\hline Single & $1.83(1.14-2.92)$ & $1.83(1.18-2.85)$ & $0.76(0.27-2.12)$ & $0.59(0.16-2.15)$ \\
\hline Family income (minimum wage) & $p=0.47 *$ & $p=0.24$ * & $p=0.003 *$ & $p=0.003 *$ \\
\hline$\leq 1$ & 1.00 & 1.00 & 1.00 & 1.00 \\
\hline $1.1-3.0$ & $1.30(0.92-1.86)$ & $1.38(1.00-1.91)$ & $0.67(0.35-1.30)$ & $0.65(0.35-1.19)$ \\
\hline $3.1-6.0$ & $1.24(0.79-1.93)$ & $1.36(0.91-2.03)$ & $0.30(0.13-0.72)$ & $0.30(0.14-0.65)$ \\
\hline $6.1-10.0$ & $1.86(0.99-3.48)$ & $1.91(1.07-3.40)$ & $0.46(0.14-1.54)$ & $0.43(0.14-1.32)$ \\
\hline$>10.0$ & $0.94(0.41-2.11)$ & $1.11(0.54-2.26)$ & $0.17(0.04-0.79)$ & $0.26(0.08-0.85)$ \\
\hline Maternal schooling (years) & $p=0.26$ * & $p=0.37$ * & $p=0.48$ * & $p=0.55 *$ \\
\hline $0-4$ & 1.00 & 1.00 & 1.00 & 1.00 \\
\hline $5-8$ & $0.84(0.63-1.12)$ & $0.89(0.68-1.16)$ & $0.76(0.39-1.46)$ & $0,78(0.43-1.43)$ \\
\hline $9-11$ & $1.29(0.85-1.98)$ & $1.19(0.80-1.77)$ & $0.41(0.12-1.39)$ & $0.49(0.17-1.37)$ \\
\hline$\geq 12$ & $0.62(0.38-1.02)$ & $0.73(0.47-1.12)$ & $0.84(0.28-2.52)$ & $0.89(0.33-2.41)$ \\
\hline Paternal schooling (years) & $p=0.001$ * & $p<0.001$ * & $p=0.33$ * & $p=0.37$ * \\
\hline $0-4$ & 1.00 & 1.00 & 1.00 & 1.00 \\
\hline $5-8$ & $0.65(0.49-0.87)$ & $0.67(0.52-0.87)$ & $1.18(0.59-2.33)$ & $0.96(0.52-1.79)$ \\
\hline$\geq 9$ & $0.58(0.42-0.81)$ & $0.55(0.41-0.75)$ & $1.53(0.66-3.56)$ & $1.44(0.67-3.08)$ \\
\hline Maternal age (years) & $p=0.37$ & $p=0.52$ & $p=0.11$ & $p=0.14$ \\
\hline$<20$ & 1.00 & 1.00 & 1.00 & 1.00 \\
\hline $20-29$ & $1.20(0.82-1.75)$ & $1.12(0.80-1.58)$ & $2.94(1.09-7.95)$ & $2.29(1.00-5.23)$ \\
\hline$\geq 30$ & $0.91(0.59-1.40)$ & $0.94(0.64-1.40)$ & $2.94(1.03-8.40)$ & $2.34(0.97-5,66)$ \\
\hline \multicolumn{5}{|l|}{ Maternal smoking during } \\
\hline pregnancy (cigarettes/day) & $p=0.22$ & $p=0.24$ & $p=0.02$ & $p=0.10$ \\
\hline No & 1.00 & 1.00 & 1.00 & 1.00 \\
\hline $1-14$ & $1.14(0.86-1.50)$ & $1.20(0.93-1.54)$ & $1.73(0.90-3.33)$ & $1.17(0.64-2.15)$ \\
\hline$\geq 15$ & $1.25(0.81-1.91)$ & $1.13(0.75-1.69)$ & $2.53(0.99-6.48)$ & $2.26(0.96-5.34)$ \\
\hline Paternal alcohol-related problems & $p=0.85$ & $p=0.68$ & $p=0.002$ & $p=0.02$ \\
\hline No & 1.00 & 1.00 & 1.00 & 1.00 \\
\hline Yes & $1.06(0.59-1.90)$ & $1.12(0.66-1.89)$ & $4.43(1.70-11.57)$ & $3.15(1.23-8.07)$ \\
\hline \multicolumn{5}{|l|}{ Maternal smoking in child's } \\
\hline infancy (cigarettes/day) & $p=0.25$ & $p=0.45$ & $p=0.95$ & $p=0.77$ \\
\hline No & 1.00 & 1.00 & 1.00 & 1.00 \\
\hline $1-14$ & $1.06(0.73-1.55)$ & $1.12(0.79-1.58)$ & $0.94(0.42-2.11)$ & $0.71(0.34-1.50)$ \\
\hline$\geq 15$ & $0.70(0.42-1.16)$ & $0.80(0.51-1.26)$ & $0.98(0.35-2.74)$ & $0.95(0.37-2.41)$ \\
\hline \multicolumn{5}{|l|}{ Paternal smoking in child's } \\
\hline infancy (cigarettes/day) & $p=0.26$ & $p=0.22$ & $p=0.76$ & $p=0.28$ \\
\hline No & 1.00 & 1.00 & 1.00 & 1.00 \\
\hline $1-14$ & $1.13(0.76-1.66)$ & $1.16(0.82-1.65)$ & $0.52(0.19-1.44)$ & $0.76(0.32-1.78)$ \\
\hline$\geq 15$ & $1.20(0.88-1.63)$ & $1.19(0.90-1.58)$ & $1.07(0.56-2.06)$ & $1.35(0.75-2.43)$ \\
\hline
\end{tabular}

* $p$ values for trend for all ordinal variables. 
cation was the only socioeconomic indicator associated with smoking prevalence in boys.

In girls, the effect of family income remained in the multivariate analysis. Maternal smoking during pregnancy was related to increased likelihood of daily smoking in girls. The strong effect of paternal alcohol-related problems for girls' smoking remained unaltered after adjustment (Table 3).

A significant interaction between gender and maternal smoking during pregnancy was observed. The effect of this variable was only significant for adolescent girls. The same was observed between gender and paternal alcohol-related problems. The effect of this variable on smoking in adolescence was significant for girls, but not for boys.

\section{Discussion}

Most studies on risk factors for smoking assess contemporary variables. Little attention has been given to early determinants of smoking behavior 16. Investigation of such factors requires longitudinal studies. In a population-based birth cohort study in Brazil, including some 6,000 children at birth, the role of early life variables on smoking behavior in adolescence was investigated. These results may help understand why some adolescents smoke and others do not. In addition, our data show different correlates of smoking in boys and girls, highlighting the need for gender-stratified analysis in the epidemiology of smoking.

Losses to follow-up represented some $20 \%$ for boys and $30 \%$ for girls. These results are relatively good since the cohort has been actively followed for almost 20 years. Unfortunately, it is not possible to follow our cohort passively, since registers in Brazil are not complete. Low socioeconomic status was associated with lower follow-up rates. In Brazil, the poor tend to change their place of residence more frequently, so locating them in home visits is challenging. However, response rates were above $60 \%$ in both genders and in all socioeconomic groups, minimizing the likelihood of selection bias. Because of different sample sizes, power to detect differences was much greater for males than for females. For example, the power to detect an odds ratio of 1.50 as significant was $90 \%$ for boys and $40 \%$ for girls if an exposure had affected $30 \%$ of the cohort. The non-significant effects of maternal age and smoking during pregnancy on smoking among girls are probably explained by sample size limitations.

Conversely to what has been found in another Latin American study 4, the prevalence of daily and weekly smoking in this cohort did not vary according to gender. The lack of gender differences in the present study may reflect that while males present declining rates in smoking, the opposite is observed among females. If no action is taken, the trend in the near future is for smoking prevalence to be greater in women. The numeric prevalence values observed in this study are not directly comparable to the literature, because studies including adolescents (e.g., 10-19 years) tend to find lower rates than the present study, which included only older adolescents. Another methodological issue is the difference between criteria used to define smoking 4 : definitions of daily smoking, occasional smoking, non-smoking, and ever smoking, for example, are not consistent across the studies. Comparison of prevalence values found in studies using different criteria may lead to biased conclusions.

In terms of socioeconomic indicators, in the crude analysis, family income and maternal and paternal schooling were associated with smoking in both genders. The only exception was that paternal schooling was not associated with smoking among girls. After adjustment, low paternal schooling was a predictor of smoking among boys, while low family income was associated with smoking among girls.

In the past, wealthier individuals were more likely than the poor to be smokers 17 . However, in recent decades an inverse association between socioeconomic status and smoking prevalence has been described ${ }^{17}$. A literature review on risk factors for smoking in Latin American adolescents confirmed this finding 4 . Because educational levels tend to be a marker of socioeconomic status, the same inverse relationship has been found between schooling and smoking 17 .

Boys born to single mothers were more likely to smoke in adolescence than those born to two-parent families. This effect was not observed among girls. This finding might be interpreted as a consequence of socioeconomic status, since the prevalence of single mothers was higher among the poor $(20.3 \%)$ in comparison to the wealthy (1.2\%). However, this result persisted even after adjusting for socioeconomic indicators. A literature review on risk factors for smoking found the same association ${ }^{4}$. Further research is needed to explore why maternal marital status influences smoking behavior in boys but not in girls.

The role of parents' behavior on adolescents' smoking prevalence is complex. Maternal smoking during pregnancy was associated with daily smoking in girls, but not among boys. Paternal alcohol-related problems were associated with a three-to-fourfold increase in smoking prevalence among girls, but had no effect on smoking among 
boys. Maternal and paternal smoking when cohort members were 2-4 years old did not predict adolescents' smoking behavior. In summary, parental behavior appears to be more important in the determination of smoking in girls than in boys. In a literature review ${ }^{4}$, parental smoking was associated with a greater likelihood of adolescent smoking, but gender-stratified analyses were not presented.

In summary, several variables were identified as having a long-term effect on smoking in adolescence. Interventions aimed at decreasing the burden of smoking might take these variables in- to account. Risk factors for smoking among boys are not consistent with those observed in girls, and gender-stratified analyses are thus required. Furthermore, "anti-smoking" campaigns should take gender differences into account, focusing separately on the most important aspects for determining smoking behavior in each gender. For example, family-based interventions may be more successful at reducing smoking among girls, because parental variables were more clearly associated with girls' behavior as compared to that of boys.

\section{Resumo}

A prevalência e os determinantes precoces do fumo na adolescência foram investigados em uma coorte prospectiva de nascimento no Brasil. Todos os nascidos vivos em hospitais de Pelotas, no Sul do Brasil, em 1982 foram incluídos em um estudo de coorte de nascimentos ( $N=$ 5.914; meninos: 3.037 ; meninas: 2.877 ). Todos os participantes do sexo masculino foram procurados em 2000 durante o alistamento militar, e 78,8\% foram localizados. Em 2001, uma amostra sistemática de 473 meninas foi entrevistada, representando uma taxa de acompanhamento de 69,1\%. Entre os homens, 48,6\% (IC95\%: 46,6-50,7) já haviam experimentado cigarro e 15,8\% (IC95\%: 14,3-17,3) eram fumantes diários. Entre as meninas, 53,1\% (IC95\%: 48,6-57,6) já haviam experimentado cigarro e 15,4\% (IC95\%: 12,1-18,7) eram fumantes diárias. Meninos filhos de mães solteiras e de pais com baixa escolaridade tiveram maior probabilidade de fumar na adolescência. Meninas pertencentes a famílias de baixa renda, com mães que fumaram durante a gravidez e pais com problemas relacionados ao álcool apresentaram maior probabilidade de fumar. Embora a prevalência de fumo tenha sido similar entre meninos e meninas, os fatores associados ao fumo variaram entre os sexos. O ambiente social parece ser 0 preditor mais forte do uso de tabaco na adolescência.

Tabaco; Comportamento na Adolescência; Estudos Prospectivos

\section{Contributors}

A. M. B. Menezes had the original idea for writing the article and led the drafting process. P. C. Hallal coordinated the data analysis. B. L. Horta collaborated with the literature review. All the authors reviewed and approved the paper's final version.

\section{Acknowledgements}

This study was supported by the Wellcome Trusts Initiative entitled Major Awards for Latin America on Health Consequences of Population Change. Earlier phases of the 1982 cohort study were funded by the International Development Research Centre (Canada), World Health Organization (Department of Child and Adolescent Health and Development and Human Reproduction Program), Overseas Development Administration (United Kingdom), United Nations Development Fund for Women, National Program for Centers of Excellence (Brazil), Conselho Nacional de Desenvolvimento Científico e Tecnológico (Brazil), and the Brazilian Ministry of Health. 


\section{References}

1. World Health Organization. The tobacco atlas. http://www.who.int/tobacco/statistics/tobacco_ atlas/en/ (accessed on 16/Jun/2005).

2. Instituto Nacional de Alimentação e Nutrição. PNSN: estatísticas sobre o hábito de fumo no Brasil. Brasília: Instituto Nacional de Alimentação e Nutrição; 1989.

3. Carlini EA, Galduroz JCF, Noto AR, Nappo AS. I levantamento domiciliar sobre o uso de drogas psicotrópicas no Brasil - 2001. São Paulo: Universidade Federal de São Paulo; 2002.

4. Malcon MC, Menezes AMB, Maia MFS, Chatkin M, Victora CG. Prevalência e fatores de risco para tabagismo em adolescentes na América do Sul: uma revisão sistemática da literatura. Rev Panam Salud Pública 2003; 13:222-8.

5. Barker DJ, Gluckman PD, Godfrey KM, Harding JE, Owens JA, Robinson JS. Fetal nutrition and cardiovascular disease in adult life. Lancet 1993; 341:93841.

6. Singhal A, Lucas A. Early origins of cardiovascular disease: is there a unifying hypothesis? Lancet 2004; 363:1642-5.

7. Horta BL, Barros FC, Victora CG, Cole TJ. Early and late growth and blood pressure in adolescence. J Epidemiol Community Health 2003; 57:226-30.

8. Ong KK, Dunger DB. Birth weight, infant growth and insulin resistance. Eur J Endocrinol 2004; 151 Suppl 3:U131-9.

9. Monteiro PO, Victora CG. Rapid growth in infancy and childhood and obesity in later life - a systematic review. Obes Rev 2005; 6:143-54.
10. Rogers I. The influence of birthweight and intrauterine environment on adiposity and fat distribution in later life. Int J Obes Relat Metab Disord 2003; 27:755-77.

11. Freud S. Sexuality and the psychology of love. New York: Touchstone; 1963.

12. Klering LR. Análise do desempenho dos municípios do Rio Grande do Sul em 1991. Revista Análise 1992; 3:211-53.

13. Hallal PC, Victora CG, Wells JCK, Lima RC. Physical inactivity: prevalence and associated variables in Brazilian adults. Med Sci Sports Exerc 2003; 35:1894-900.

14. Victora CG, Huttly SR, Fuchs SC, Olinto MT. The role of conceptual framewords in epidemiological analysis: a hierarchical approach. Int J Epidemiol 1997; 26:224-7.

15. Victora CG, Barros FC, Lima RC, Behague DP, Gonçalves H, Horta BL, et al. The Pelotas birth cohort study, Rio Grande do Sul, Brazil, 1982-2001. Cad Saúde Pública 2003; 19:1241-56.

16. Audrain-McGovern J, Rodriguez D, Tercyak KP, Cuevas J, Rodgers K, Patterson F. Identifying and characterizing adolescent smoking trajectories. Cancer Epidemiol Biomarkers Prev 2004; 13:202334.

17. World Bank. Curbing the epidemic: governments and the economics of tobacco control. Washington DC: World Bank Publications; 1999.

Submitted on 25/Aug/2005

Final version resubmitted on 22/Dec/2005

Approved on 26/Dec/2005 